\title{
Financial mindset, entrepreneurial mindset, and personal finance of university students
}

\author{
Aplonio Atto ${ }^{1 *}$ and Ariyon Stefen Ndun ${ }^{2}$ \\ ${ }^{1}$ Department of Accounting, Faculty of Management, \\ Universitas Persatuan Guru 1945 NTT \\ Jalan P.A. Manafe, Kupang 85111, Indonesia \\ amkeniatto2018@gmail.com \\ ${ }^{2}$ Department of Accounting, Faculty of Management, \\ Universitas Persatuan Guru 1945 NTT \\ Jalan P.A. Manafe, Kupang 85111, Indonesia \\ fkip.j3p@gmail.com
}

\begin{abstract}
The purpose of the research is identifying the influence of financial mindset and entrepreneurial mindset to personal finance. This is a quantitative research with descriptive analysis and simple linear regression analysis. The research's respondents are eighty-one students of Faculty of Economics, Universitas Persatuan Guru 1945 NTT. The sampling technique is random sampling with questionnaire as data collection method. The research instrument for financial mindset is adopted from "OTM The Knew Rules of Building Wealth (CNBC)" by Rhodes (2010) and the entrepreneurship mindset's instrument is adopted from 'Building E-Businesses series and Personal finance' by Spinela, Yang \& Laster (2007). The results imply that both the financial mindset and entrepreneurial mindset have a significant and simultaneous influence on personal finance.
\end{abstract}

Keywords: entrepreneurial mindset; financial mindset; personal finance.

Received: July 3, 2019; Accepted: August 21, 2019; Published: October 17, 2019

*Corresponding author

Email: amkeniatto2018@gmail.com

How to cite this document:

Otto, A., \& Ndun, A. S. (2019). Financial mindset, entrepreneurial mindset, and personal finance of university students. BISMA (Bisnis dan Manajemen), 12(October), 29-42. https://doi.org/10.26740/bisma.v12n.p29-42 
Financial mindset, entrepreneurial mindset, and personal finance of university students

\begin{abstract}
Abstrak
Tujuan dari penelitian ini adalah untuk menginvestigasi pengaruh financial mindset dan entrepreneurial mindset terhadap personal finance. Penelitian ini adalah penelitian kuantitatif dengan menggunakan analisis deskriptif dan analisis regresi linear sederhana dan berganda. Responden berasal dari Fakultas Ekonomi Universitas Persatuan Guru 1945 NTT yang berjumlah 81 orang, dan teknik sampling yang digunakan adalah random sampling. Instrumen penelitian diadopsi dari "OTM The Knew Rules of Building Wealth (CNBC)" dari Rhodes (2010) dan entrepreneurial mindset diadopsi dari Building EBusinesses series dan personal finance yang dikembangkan dari Spinela, Yang, dan Lester (2007). Hasil penelitian menunjukkan bahwa: Ada pengaruh yang signifikan antara financial mindset terhadap personal finance; Ada pengaruh yang signifikan antara entrepreneurial mindset terhadap personal finance; dan Ada pengaruh yang signifikan antara financial mindsets dan entrepreneurial mindset secara simultan terhadap personal finance.
\end{abstract}

Kata kunci: entrepreneurial mindset; personal finance; pola pikir keuangan.

\title{
INTRODUCTION
}

The information era offers various challenges due to changes in various fields of life such as social, economic, business, technology, science and knowledge aspects. The financial sector also experienced many significant changes along with the growing financial instruments that offer respective advantages and risks. These changes put personal financial management becomes relevant and significant. Therefore, everyone faces how to manage economic resources (money) intelligently as more demanding information era. This research has managerial implication as its purpose to identify the personal finance management in the perspective of the financial mindset and entrepreneurial mindset.

Along with the development of the field of finance, many researchers have attracted to examine how someone should or normatively manage their finance. In other words, there are factors that significantly influence someone to successfully manage their money. Pavani and Anirudh (2010) explain that mindset is a significant factor for investor's decision making. According to these researchers, understanding the mindset of investors will benefit the companies in conducting promotion strategy because the company will be able to gain their investor insight. Furthermore, by understanding their financial mindset, investors will easily arrange the appropriate investment portfolio in order to obtain profitable returns while undermine the degree of investment's deviation risk. Kadariya (2014) also examines that after several decade, the interest in investing is increasing along with the increasing investment uncertainty that become factors that influence the financial decisions of investors. In this case, information plays an important role in creating the appropriate financial decision. To use information appropriately, investors needs the appropriate financial mindset so that they able to mix information to make financial decisions and increase their wealth. White (2015) 
explains the similar statement about the significance of financial mindset to increase investor opportunity to make the appropriate financial decisions which affects their wealth. This supports Bef (2014) that the financial mindset determines investor success. Therefore, an investor who wants to build a financial mindset will have the opportunity for success including achieving their financial freedom.

This study uses the financial mindset factor that will be combined with entrepreneurial mindset factors as predictors of the success of someone in managing their finance (personal finance). Therefore, the purpose of this research is to prove that these two factors (financial mindset and entrepreneurial mindset) are predictors of personal finance.

\section{Financial Mindset}

Based on the previous explanation that financial intelligence is a characteristic of personal finance of an investor, financial mindset also becomes the determinants of effective investment strategy of investor. Sundjaja et al (2012) stated that financial management knowledge is not only important for a company, but also for managing family finance and individual finance. Simply said, the family financial planning is related to how much money received as income, how much money is consumed for the needs of each family and how much money is saved to achieve family financial goals.

Ida and Lisan (2013) stated that the term financial management implies the flow of funds chanelled based on the investor's financial plan. The flow of funds is a changed in funds allocation comes from various sources such as the investors who invest their capital in the form of company shares, creditors who lend their money, and profits from past years that retained in the company. The funds derived from these sources are bound in a number of uses such as in the form of fixed assets used to produce goods or services, inventories used for the purpose of production and sale, accounts receivable in the context of granting credit to customers, cash and securities used for transactions and liquidity goals. This means that financial management regulates the budget of the source of funds (income) and the budget allocation of funds (expenditure) that directed based on the financial plan and investment purpose to get the maximum wealth.

As for previous research by Fidelity (2011) that adequate financial preparation for retirement can be done if someone has the right financial mindset. In this case, the financial mindset is needed as a form of awareness about the funds needed at retirement. There different source which explain that a success of managing finances requires a financial mindset although in the long term, the good financial mindset and appropriate financial decisions did not assure investor's happiness (White, 2011). Meanwhile, Pavani \& Anirudh (2010) explained that the existence of a financial mindset is a basic aspect needed for 
financial success. The better the financial mindset, the more knowledge will be earned by investor to manage their money. Kadariya (2012) added that the financial mindset is a fundamental factor for someone to make an appropriate financial decision which includes investment decisions to build financial assets. Therefore, according to Robert (2011), being successful or successful in finance requires the right mindset, because it will make extraordinary effort (miracle) to improve their life which including how to manage their finance. Renner (2015) confirmed that the success of managing money requires the right mindset and financial mindset to be succeed.

\section{Entrepreneurial Mindset}

Mathisen and Arnulf (2014) in "Entrepreneurial Mindset: theoretical foundations and empirical properties of a Mindset Scale" developed a study about the measurement scale for entrepreneurial mindset. The compulsive mindset about entrepreneurial activity is mediated by the implemental mindset. Therefore, compulsiveness is part of a prominent entrepreneur's impression of others, and caused by mindset and not by personality. A discriminant analysis to the top five personality factors supports this statement because neuroticism does not correlate with entrepreneurship mindset. Meanwhile the other characteristics related to mindset predicted by contemporary research.

Indarti \& Rostinasi (2012) explained that the influence of entrepreneurship education has been considered as one of the important factors to foster and develop desire, passion and entrepreneurial behavior among the younger generation. Related to the influence of entrepreneurship education, it is necessary to have an understanding on how to develop and encourage the potential young entrepreneurs while they become a university student. Several previous studies mentioned that the entrepreneurial traits of students namely their attitudes, behaviors and knowledge about entrepreneurship is a source for the emergence of future entrepreneurs and will shape their tendency to open new businesses in the future.

Pihie \& Sani (2014) emphasized that an entrepreneurial mindset is needed to improve the economy so that students should be taught and understood. Through the results of both the researchers study found that the role of universities as institutions of learning and education needs to instill the values of entrepreneurship to encourage the creation of a good entrepreneurial mindset in students. One of the advantages by having a good entrepreneurial mindset is their ability to manage resources appropriately made them possible to manage money as an input for doing business. Based on the empirical facts and the results of previous studies, this study uses financial mindset factors that will be combined with entrepreneurial mindset factors as predictors of the success of someone managing their finance (personal finance). 


\section{METHODS}

The research method is quantitative research with descriptive analysis approach and multiple regression analysis tools as the analytical tools and for testing the first to second hypotheses. Before conducting the multiple regression analysis, the validity, reliability, descriptive, normality, and classical assumption will be tested. The total population in the study was 422 respondents from the entire Faculty of Economics, Universitas Persatuan Guru 1945 NTT, in which 170 people from Management program, 132 people from accounting, and 120 people from economic development program. Based on the formula of Yamane (1974) in Supramono and Utami (2004), the research sample of 81 people was obtained in which 27 people come from each study program. The sampling technique is random sampling technique. The research instrument in the form of a questionnaire that identify the financial mindset dimension by 32 questions based on OTM The Knew Rules of Building Wealth by Rhodes (2010) and 22 questions of entrepreneurship mindset adopted from the Building E-Businesses series, and 17 questions of personal finance developed from Spinela, Yang, and Lester (2007). All of these instruments were adopted and developed by the researcher based on the situation and condition of the respondent.

The operational definition of personal finance is the art and science of managing resources (money) from students (individuals) related to buying and owning as much productive assets as possible, managing expenses, careful debt selection, spare money for the future, and having protection on each financial instrument. Financial mindset is a mental attitude or belief that becomes the basis for interpreting financial information and to make financial decisions so that the students can minimize mistakes in financial management. Meanwhile, the entrepreneurial mindset is innovation and passion in pursuing opportunities and facilitating actions to take advantage of these opportunities so that students have the characteristics and traits of entrepreneurial orientation.

\section{RESULT AND DISCUSSION}

\section{Result}

The results of the validity test to 32 financial mindset instrument items has resulted 12 items that have a value of $\mathrm{r}$ count $<0.3$, namely item number $1,6,7$, $10,13,14,16,22,23,26,27, \& 29$. Accordingly, 12 item numbers were declared invalid and were excluded from the analysis. Meanwhile, the remaining 20 items are declared valid because $r$ count $>0.3$. Thus, 20 items of financial mindset instruments are declared valid. Whereas the results of the validity test of 22 items of instrument of entrepreneurial mindset showed 6 items that had a value of $r$ count $<0.3$ namely items number $2,8,14,16,20 \& 21$. Thus, there were 6 items declared invalid and excluded from the analysis. Meanwhile, the remaining 16 items are declared valid because $r$ count $>0.3$. The results of the validity test of 17 
Financial mindset, entrepreneurial mindset, and personal finance of university students

items of instrument of personal finance has resulted 5 items that have a value of $\mathrm{r}$ count $<0.3$, namely item number $3,6,7,10, \& 11$. Thus, there are 5 items that are declared invalid and excluded from analysis. In the other side, the remaining 12 items are declared valid because $r$ count $>0.3$.

Based on the output in the reliability test results, it was found that all variables have a Cronbach alpha coefficient's value which larger than the minimum limit set. The lowest alpha coefficient occurs in the financial mindset variable (0.823), personal finance $(0.842)$ and the highest alpha coefficient occurs in the entrepreneurial mindset variable $(0.855)$. Because of the alpha coefficient is $>0.6$, all instruments declared reliable. Through the descriptive statistical test results, it is known that the financial mindset of students of the Faculty of Economics at Universitas Persatuan Guru 1945 NTT tends to be high to very high. To be exact, $30 \%$ of students have a financial mindset in the very high category, and by $59 \%$ in the high category; $40 \%$ of students have an entrepreneurial mindset in the medium category, by $41 \%$ in the high category, and $10 \%$ in the very high category; and student personal finance is in the high category (43\%) and the category is very high (43\%) (see Table 1).

Table 1. Description of Variable Measurement

\begin{tabular}{ccccc}
\hline Variable & Category & Range & $\mathbf{N}$ & $\%$ \\
\hline Financial Mindset & Very high & $4,21-5,0$ & 24 & $30 \%$ \\
& High & $3,41-4,2$ & 48 & $59 \%$ \\
& Medium & $2,61-3,4$ & 8 & $10 \%$ \\
& Low & $1,81-2,6$ & 1 & $1 \%$ \\
& Very low & $1,00-1,8$ & 0 & $0 \%$ \\
Entrepreneurial & Total & & 81 & $100 \%$ \\
Mindset & Very high & $4,21-5,0$ & 10 & $12 \%$ \\
& High & $3,41-4,2$ & 33 & $41 \%$ \\
& Medium & $2,61-3,4$ & 32 & $40 \%$ \\
& Low & $1,81-2,6$ & 6 & $7 \%$ \\
Personal Finance & Very low & $1,00-1,8$ & 0 & $0 \%$ \\
& Total & & 81 & $100 \%$ \\
& Very high & $4,21-5,0$ & 35 & $43 \%$ \\
& High & $3,41-4,2$ & 35 & $43 \%$ \\
& Medium & $2,61-3,4$ & 10 & $12 \%$ \\
& Low & $1,81-2,6$ & 1 & $2 \%$ \\
& Very low & $1,00-1,8$ & 0 & $0 \%$ \\
& Total & & $100 \%$ \\
\hline
\end{tabular}

Source: Result of the research.

The results of the classic assumption test for normality, multicollinearity, heteroscedasticity, and linearity indicate that all conditions are met, and can be continued on the hypothesis test (see Appendix 1).

From the results of the first test in table 2, it was found that there was an influence of the financial mindset variable on personal finance variables, where $t$ 
count $>\mathrm{t}$ table $(2,353>1,99045)$. Whereas the results of the second hypothesis $t$ test showed that there was an influence of the entrepreneurial mindset variable on personal finance, where $t$ count $>t$ table $(3,199>1,99045)$. In addition to the $t$ test, the results of the third hypothesis $F$ test in Table 3 show that there is a simultaneous influence of the financial mindset and entrepreneurial mindset variables on personal finance where $\mathrm{F}$ count $>\mathrm{F}$ table $(11,112>3.11)$. Meanwhile, there is the effective contribution of financial mindset and entrepreneurial mindset about $22.2 \%$.

Table 2. Result of T Test

\begin{tabular}{ccccccc}
\hline & & \multicolumn{2}{c}{$\begin{array}{c}\text { Unstandardized } \\
\text { Coefficients }\end{array}$} & $\begin{array}{c}\text { Standardized } \\
\text { Coefficients }\end{array}$ & t & Sig. \\
& \multicolumn{1}{c}{ B } & Std. Error & Beta & & \\
\hline \multirow{4}{*}{1} & (Constant) & 20.182 & 6.165 & & 3.274 & .002 \\
& Financial Mindset & .172 & .073 & .246 & 2.353 & .021 \\
& Entrepreneurial & .254 & .080 & .335 & 3.199 & .002 \\
\hline & Mindset & .254 &
\end{tabular}

Source: Result of the research.

Table 3. Result of F Test

\begin{tabular}{ccccccc}
\hline & Model & Sum of Squares & df & Mean Square & F & Sig. \\
\hline 1 & Regression & 890.584 & 2 & 445.292 & 11.112 & $.000^{\mathrm{a}}$ \\
& Residual & 3125.811 & 78 & 40.074 & & \\
& Total & 4016.395 & 80 & & & \\
\hline
\end{tabular}

Source: Result of the research.

\section{Discussion}

The results of this study indicate that there is a positive and significant influence between the financial mindset on personal finance; positive and significant influence of entrepreneurial mindset on personal finance, and positive and significant effect of entrepreneurial mindset and personal finance simultaneously to personal finance. The results of this study support previous research conducted by Fidelity (2011), White (2011, Pavani \& Anirudh (2010), and Kadariya (2012), which stated that the financial mindset influenced personal finance. The results of this study also confirmed the results of previous studies, who discovered the influence of entrepreneurial mindset on personal finance (Indarti \& Rostinasi, 2012; Pihie \& Sani, 2014).

The empirical evidence shows that the majority of students have high category entrepreneurial mindset. This result proves that the students of the Faculty of Economics, Universitas Persatuan Guru 1945 NTT have knowledge and able to minimize mistakes in financial decision making besides having the financial mindset very helpful in their money management; innovation and enthusiasm in pursuing opportunities and facilitating actions to take advantage of those opportunities; and have the ability in managing personal finances in relation to debt, set aside for the future, retirement planning, and have protection. In other 
words, the students already create a process of planning, analyzing and controlling financial activities (Gitman in Krishna, Sari, \& Rosadi, 2012). Students must have financial responsibility, because the responsibility precedes knowledge and freedom, the responsibility is concrete, is substitution and is in an asymmetrical framework (Dami, Pandu, Anakotta, \& Sahureka, 2019).

In the aspects of financial mindset, entrepreneurial mindset, and personal finance students need to be vigilant so as not to get caught up and trapped themselves into the concept of neoliberal pedagogy, in which education turns become "slave" of economics and business, even reason is used only for one purpose, collecting economic benefits regardless of the price to be paid (Dami, 2019).

The results of this study indicate that the better the financial mindset, the better the personal finance of respondents. Students who have the appropriate knowledge about the value of money will increase one's ability to manage their money (Kadariya, 2012). Moreover, this research also found that students who have good self-confidence, the desire to try and renew how to manage money will be good in manage their financial resources. In addition, there are other interesting findings that respondents have good confidence that their financial condition will be better than their parents even though the majority of students are still funded by parents. They are also determined to be better in personal finance by having continuous efforts in improving ways to manage money. Financial mindset is a critical success factor in the era of uncertainty and becomes very important to be used in era of transparent and free-flow of financial information. Financial mindset also has a role to minimize mistakes in financial decision making and assist people in money management (Delliana, 2016).

Another interesting finding is that the better the entrepreneurial mindset will be very helpful in making detailed financial plans so that spending patterns will be even better. This means that students who have the awareness to make detailed plans are explicitly useful for making various posts in the budget so that they do not necessarily spend money without thinking about the benefits that will be obtained later. Pihie \& Sani (2009) stated that an entrepreneur tends to be professional in managing his finance. Furthermore, by successfully managing various resources, the motivation to become better at managing money will continue to be maintained. In the world of education, entrepreneurship education programs are associated with efforts to filter the personality or mindset of each individual (Raposo, do Paco, \& Ferreira, 2013). Entrepreneurship is not just a way to start a new business, but also prepare students to have characteristics and traits related to entrepreneurial orientation (Van, Louw, \& Venter, 2013). Entrepreneurial mindset explains innovative and enthusiasm in pursuing opportunities and facilitating actions to take advantage of these opportunities (Senges, 2007 in Scheepers, 2012). At the individual level, entrepreneurial mindset is a philosophy of life, while at the organizational level, entrepreneurial 
mindset is part of the culture and climate of the company that is not clearly stated. One indicator used to measure the entrepreneurial mindset is entrepreneurial self efficacy. Entrepreneurial self efficacy measures a person's confidence in his ability to be successful entrepreneurs in the future (McGee, Peterson, Mueller, \& Sequeira, 2014). Personal finance is also caused by the awareness not to procrastinate doing something useful such as taking the initiative to fix ways to manage money for success. In other words, an entrepreneurial mindset is needed to reduce laziness or ignorance to fix economic resources management for success. Students who have good personal finance could certainly make personal financial decisions which include charity, education and protection investment, and cost of living (Karvof, 2014).

\section{CONCLUSION}

Based on the entire analysis process, the three hypotheses are accepted so it is necessary to consider these two predictive factors if someone wishes to succeed in managing finance, achieving of financial freedom and achieving maximum wealth. The results also showed that: (1) there was a significant influence of financial mindset on personal finance; (2) there is a significant influence of entrepreneurial mindset on personal finance; and (3) there is a significant influence of financial mindset and entrepreneurial mindset simultaneously on personal finance.

This research also provides benefits such as increasing scientific knowledge in Indonesia about the significance of the mindset factor for success and the need for continuous efforts to prepare students to have a good mindset to realize the goal of financial well-being. In addition, in the future, this research can still be developed b synergizing the two mindset categories in this study with another mindset such as the social mindset.

\section{REFERENCES}

Bef, J. E. (2014). Mindset Sukses Jalur Cepat Menuju Kebebasan Keuangan. ISBN 978-1-933564-99-9

Delliana, Egi. (2016), Analisis Faktor-faktor Penentu Mindset Financial. Skripsi(Unpublished).Universitas Muhammadiyah Purwakerto. Purwakerto.

Dami, Z.A. (2019). Pedagogi Shalom: Analisis Kritis Terhadap Pedagogi Kritis Henry A. Giroux dan Relevansinya Bagi Pendidikan Kristen di Indonesia. Jurnal Filsafat, Vol. 29, No. 1 (2019), p. 134-165, doi: 10.22146/jf.42315

Dami, Z. A., Pandu, I., Anakotta, E., \& Sahureka, A. (2019). The contribution of levinas' conception of responsibility to the ethical encounter counselorcounselee. International Journal of Social Sciences and Humanities, 3(2), 71-83. https://doi.org/10.29332/ijssh.v3n2.291 
Fidelity. (2011). Retirement Mindset Survey Executive Summary of Key Findings. Fidelity Investments and the Pyramid Design logo are registered service marks of FMR LLC. 573202.1.0

Ida, Lisan, \& Hengky, E. (2013). Pengaruh Tingkat Pendidikan dan Pendapatan Pasangan Suami- Istri Terhadap Pengambilan Keputusan Keuangan Keluarga. $\quad$ http://henky.lecturer.maranatha.edu/wpcontent/uploads/2012/02/Family-Financial-Decision-Making.pdf, diakses 16 April 2019.

Indarti, N. \& Rostiani, R. (2012). Intensi Kewirausahaan Mahasiswa: Studi Perbandingan Antara Indonesia, Jepang dan Norwegia. Jurnal Ekonomika dan Bisnis Indonesia, Vol. 23, No. 4.

Krishna, A, Rofaida, R. \& Sari, M. (2012). Analisis Tingkat Literasi Keuangan di Kalangan Mahasiswa dan Faktor-faktor yang Mempengaruhinya (Survey pada Mahasiswa Universitas Pendidikan Indonesia). Proceedings of The 4th International Conference on Teacher Education; Join Conference UPI \& UPSI Bandung, Indonesia.

Karvof, A. (2014). Kaya dengan CEPIL; Cara Cerdas Meraih Kekayaan dan Keberkatan Finansial. Elex Media Komputindo. Jakarta.

Kadariya, S. (2014). Factors Affecting Investor Decision Making: A Case of Nepalese Capital Market. Journal of Research in Economics and International Finance (JREIF) Vol. 1(1) pp. 16-30, July 2012 Available online http://www.interesjournals.org/JREIF Copyright (C) 2012 International Research Journals.

McGee, J. E., Peterson, M., Mueller, S. L., \& Sequeira, J. M. (2014). Entrepreneurial Self-Efficacy: Refining the Measure. Entrepreneurship Theory and Practice, 33(4), 965-988.

Pavani, CH. \& Anirudh, P. (2010). Investor Behavior Analysis. Submitted to II International Conference on, Management Practices for Sustainable Growth"e (ICMPSG 2010) during 28-30 July 2010, conducted by Annamalai University, Dept. of Business Management, Annamalai Nagar, Tamilnadu.

Pihie, Z. A. L. \& Sani, A, S. A. (2014). Exploring The Entrepreneurial Mindset of Students: Implication For Improvement of Entrepreneurial Learning At University. Uluslararas1 Sosyal Ara tırmalar Dergisi The Journal of International Social Research Volume $2 / 8$.

Robert, G. (2011). The Millionaire Mindset How Ordinary People Can Create Extraordinary Income. Life Success Publishing, LLC.

Renner, S. (2015). "Inside The Millionaire Mindset" "Universal Success Consciousness". Net Profit Power Publishing. 
Raposo, M., do Paco, A., \& Ferreira, J. (2013). Entrepreneur's Profile: A Taxonomy of Attributes and Motivations of University Students. Journal of Small Business and Enterprise Development, 15(2), 404-418.

Rhodes, M. J. (2010). Money Mindset Quiz? Award-winning author of The Freedom Code: Simple Solutions for Life's Major Challenges and The Billionaire Mindset Guide. E-book and CD Series.

Rogeliodavila.com. (2000). Building E-Businesses series. Retrieved from http://www.rogeliodavila.com/eblsca/docs/m03entrptool.pdf, 2 June 2019.

Scheepers, M. J. (2012). Entrepreneurial Mindset of Information and Communication Technology Firms. Journal of Information Management, 10(4).

Spinella, M., Yang, B., \&Lester, D. (2007). Development of the Executive Personal Finance Scale. International Journal of Neuroscience, 117(3):30113, DOI: 10.1080/00207450500534043.

Van, E. S., Louw, L., \& Venter, D. (2013). Entrepreneurial Traits of Undergraduate Commerce Students: A Three-Country Comparison. Management Dynamic, 14(3), 26-43.

White, B. (2015). Estimate-related Disclosures, Investor Mindset and the Illusion of Precision in Financial Statement Estimates. Retrived from: www.google.com-pdf financial mindset, 9 April 2019.

Appendix 1. Classic Assumption Test Results

\begin{tabular}{|c|c|c|c|}
\hline $\begin{array}{c}\text { Classical } \\
\text { Assumption Test }\end{array}$ & Test & Results & Conclusion \\
\hline Normality & $\begin{array}{l}\text { Kolmogorov- } \\
\text { Smirnov Test }\end{array}$ & $\begin{array}{c}\text { Sig. Financial Mindset }=0,738 \\
\text { Sig. Entrepreneurial Mindset }= \\
0,780 \\
\text { Personal Finance }=0,386\end{array}$ & $\begin{array}{c}\text { Normal } \\
\text { distributed data }\end{array}$ \\
\hline Multicollinearity & $\begin{array}{l}\text { Variance } \\
\text { Inflation } \\
\text { Factor (VIF) }\end{array}$ & $\begin{array}{c}\text { VIF Financial Mindset }=1,097 \\
\text { VIF Entrepreneurial Mindset }= \\
1,097\end{array}$ & $\begin{array}{c}\text { No } \\
\text { multicollinearity }\end{array}$ \\
\hline Heteroscedasticity & Glejser Test & $\begin{array}{l}\text { Sig. Financial Mindset }=0,951 \\
\text { Sig. Entrepreneurial Mindset }= \\
0,089\end{array}$ & $\begin{array}{c}\text { No } \\
\text { heteroscedasticity }\end{array}$ \\
\hline Linearity & Test of Linearity & $\begin{array}{c}\text { Sig. financial mindset }=0,309 \\
\text { Sig. entrepreneurial mindset }= \\
0,735\end{array}$ & $\begin{array}{l}\text { There is a linear } \\
\text { relationship } \\
\text { variabel X and Y }\end{array}$ \\
\hline
\end{tabular}

Source: Result of the research.

Appendix 2. Questionnaire of Personal Finance

\begin{tabular}{llllll}
\hline \multirow{2}{*}{ No. } & \multicolumn{1}{c}{ Question } & \multicolumn{4}{c}{ Answer } \\
& & $\mathbf{2}$ & $\mathbf{3}$ & $\mathbf{4}$ & $\mathbf{5}$ \\
\hline 1 & I tend to spend money as soon as I get it. & & & & \\
2 & I worked hard to earn money. & & & & \\
3 & I worked for a long time to increase wealth. & & & \\
\hline
\end{tabular}




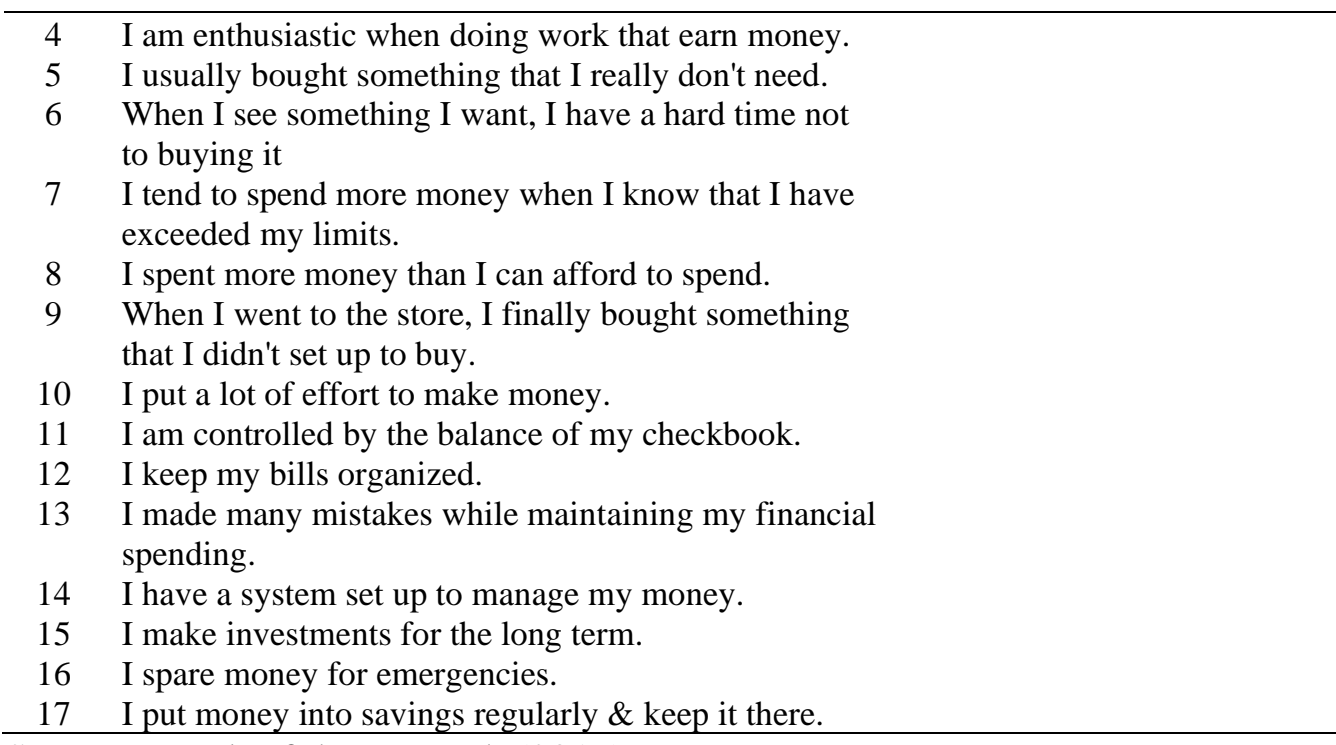

Source: Result of the research (2019)

Appendix 3. Questionnaire of Financial Mindset

\begin{tabular}{|c|c|c|c|c|c|c|}
\hline \multirow{2}{*}{ No } & \multirow{2}{*}{ Question } & \multicolumn{5}{|c|}{ Answer } \\
\hline & & 1 & 2 & 3 & 4 & 5 \\
\hline 1 & I do not have enough of money & & & & & \\
\hline 2 & $\begin{array}{l}\text { Money is "evil" causes addiction and the root of all } \\
\text { crime. }\end{array}$ & & & & & \\
\hline 3 & I can not afford luxury & & & & & \\
\hline 4 & Rich people are stingy, arrogant, and greedy. & & & & & \\
\hline 5 & I should have given twice as much as I received. & & & & & \\
\hline 6 & One time becomes a wastrel, always be a wastrel. & & & & & \\
\hline 7 & It's too difficult to change from being poor to being rich. & & & & & \\
\hline 8 & When I die, I don't want to leave anything behind. & & & & & \\
\hline 9 & My education level suits with my income level. & & & & & \\
\hline 10 & If I become debt-free, everything will be OK. & & & & & \\
\hline 11 & I feel confident that I can control my financial future. & & & & & \\
\hline 12 & I am often intimidated by financial problems. & & & & & \\
\hline 13 & $\begin{array}{l}\text { I described myself as someone who understands } \\
\text { financially. }\end{array}$ & & & & & \\
\hline 14 & My debt level illustrates the quality of my life. & & & & & \\
\hline 15 & Savings is prepared for the unexpected problems. & & & & & \\
\hline 16 & $\begin{array}{l}\text { The wealth provides security, stability, and a peaceful } \\
\text { mind rather than pleasure, freedom, and luxury. }\end{array}$ & & & & & \\
\hline 17 & I do not understand where I should save my money. & & & & & \\
\hline 18 & I don't feel urgent to save right now. & & & & & \\
\hline 19 & $\begin{array}{l}\text { I have a plan to start to save for the future, but I don't } \\
\text { have enough time. }\end{array}$ & & & & & \\
\hline 20 & $\begin{array}{l}\text { I save for the future but I don't have a long-term } \\
\text { planning. }\end{array}$ & & & & & \\
\hline 21 & I need a help to understand the basic financial literacy. & & & & & \\
\hline 22 & I save for afford my tuition fee. & & & & & \\
\hline 23 & $\begin{array}{l}\text { As the most important part, I save today to buy what } \\
\text { most important thing to me }\end{array}$ & & & & & \\
\hline 24 & I consider very carefully when investing my money & & & & & \\
\hline 25 & I understand the difference of good debt and bad debt & & & & & \\
\hline 26 & $\begin{array}{l}\text { I need assistance in having financial knowledge when I } \\
\text { decide to change my investment plan }\end{array}$ & & & & & \\
\hline
\end{tabular}




\begin{tabular}{|c|c|c|c|c|c|c|}
\hline \multirow{2}{*}{ No } & \multirow{2}{*}{ Question } & \multicolumn{5}{|c|}{ Answer } \\
\hline & & 1 & 2 & 3 & 4 & 5 \\
\hline 27 & Although I need assistance from others, but I believe that & & & & & \\
\hline & I am the best on it (financial knowledge) & & & & & \\
\hline 28 & I want special help, as such I am nowadays. & & & & & \\
\hline 29 & I am afraid of spending my money & & & & & \\
\hline 30 & I am spending my time relating to managing my money. & & & & & \\
\hline 31 & $\begin{array}{l}\text { I become more anxious about the health cost and saving } \\
\text { for the future compared to short-term financial needs. }\end{array}$ & & & & & \\
\hline 32 & $\begin{array}{l}\text { I know that I need extra saving, but I also need to have } \\
\text { extra financial sources for my future }\end{array}$ & & & & & \\
\hline
\end{tabular}

Source: Result of the research.

Appendix 4. Questionnaire of Entrepreneurial Mindset Self-Assessement

\begin{tabular}{|c|c|c|c|c|c|c|}
\hline \multirow[t]{2}{*}{ No } & \multirow[t]{2}{*}{ Question } & \multicolumn{5}{|c|}{ Answer } \\
\hline & & 1 & 2 & 3 & 4 & 5 \\
\hline 1 & $\begin{array}{l}\text { I believe that the entrepreneurial mindset helps me } \\
\text { succeed in college and in life. }\end{array}$ & & & & & \\
\hline 2 & $\begin{array}{l}\text { I have investigative skills and knowledge curiosity that } \\
\text { allows me to be entrepreneurial. }\end{array}$ & & & & & \\
\hline 3 & I can develop an entrepreneurial mindset. & & & & & \\
\hline 4 & I made a decision in supporting my vision. & & & & & \\
\hline 5 & $\begin{array}{l}\text { I know the difference between investing and spending } \\
\text { time. }\end{array}$ & & & & & \\
\hline 6 & I choose to respond rather than to react toward situations. & & & & & \\
\hline 7 & I can reconstruct a problem as a potential opportunity. & & & & & \\
\hline 8 & I can create methods that make work meaningful and fun. & & & & & \\
\hline 9 & $\begin{array}{l}\text { I developed creative and different solutions to the } \\
\text { existence of problems. }\end{array}$ & & & & & \\
\hline 10 & $\begin{array}{l}\text { I understand how my brain learns new information and } \\
\text { how I can master these skills. }\end{array}$ & & & & & \\
\hline 11 & I know how to use my time wisely. & & & & & \\
\hline 12 & $\begin{array}{l}\text { I recognize the importance of reasoning for achieving my } \\
\text { goals / goals. }\end{array}$ & & & & & \\
\hline 13 & $\begin{array}{l}\text { I can distinguish between the appearance of wealth and } \\
\text { true wealth. }\end{array}$ & & & & & \\
\hline 14 & I understand the importance of delaying satisfaction. & & & & & \\
\hline 15 & I recognize that social influences affect my life. & & & & & \\
\hline 16 & $\begin{array}{l}\text { I can distinguish between positive and negative influences } \\
\text { in my life. }\end{array}$ & & & & & \\
\hline 17 & $\begin{array}{l}\text { I have a positive support network from family, friends, } \\
\text { and others who set an example /role model for me. }\end{array}$ & & & & & \\
\hline 18 & $\begin{array}{l}\text { I recognize the importance of perseverance in accelerating } \\
\text { the achievement of ideals / goals. }\end{array}$ & & & & & \\
\hline 19 & I can identify ways to achieve personal well-being. & & & & & \\
\hline 20 & $\begin{array}{l}\text { I recognize that the entrepreneurial mindset can help me } \\
\text { live the life that I have imagined. }\end{array}$ & & & & & \\
\hline 21 & I can act and deliver on my promises. & & & & & \\
\hline 22 & $\begin{array}{l}\text { I can solve problems through the knowledge I have } \\
\text { gained. }\end{array}$ & & & & & \\
\hline
\end{tabular}

Source: Result of the research. 